\title{
DISTRIBUTION AND DENSITY OF BACTERIA IN SUBTROPICAL FLOODED RICE GROWING AREAS IN BRAZIL
}

\author{
RECHE, M. H. L. R. ${ }^{1}$ and FIUZA, L. M. ${ }^{1,2}$ \\ ${ }^{1}$ Laboratório de Microbiologia, Centro 2, Universidade do Vale do Rio dos Sinos, UNISINOS, C.P. 275, \\ CEP 93001-970, São Leopoldo, RS, Brazil \\ ${ }^{2}$ EEA/Instituto Riograndense do Arroz, C.P. 29, CEP 94930-030, Cachoeirinha, RS, Brazil \\ Correspondence to: Lidia Mariana Fiuza, Laboratório de Microbiologia, Centro 2, Universidade do Vale do Rio dos \\ Sinos, UNISINOS, C.P. 275, CEP 93001-970, São Leopoldo, RS, e-mail: fiuza@unisinos.br \\ Received May 12, 2003 - Accepted December 4, 2003 - Distributed August 31, 2005
}

(With 4 figures)

\begin{abstract}
Since microorganisms are important components in the structure and function of water systems, the present paper reports work done to identify groups making up bacterial communities present in rice irrigation water. To this end, water samples were collected in five rice-growing areas of Rio Grande do Sul State, Brazil. The identification of the main bacterial groups found in flooded areas was carried out based on colony morphology, taking into account shape, elevation, and edges. Internal and external cell structure was characterized as cocci or rod, gram-positive or gram-negative, and spore forming or not. The results obtained regarding density and bacterial distribution in the water samples from rice growing areas of RS showed a higher abundance of morphotypes of bacterial colonies in the irrigation channels $\left(\mathrm{F}_{1,12}=8.74 ; \mathrm{p}<0.05\right)$ when compared to the culture plots in the five production regions, and in the final culture phase $\left(\mathrm{F}_{1,12}=8.86 ; \mathrm{p}<0.05\right)$. In the five rice production areas the occurrence of gram-positive and spore-forming rods was prevalent. Rods showed more abundance $\left(\mathrm{F}_{1,26}=15.12 ; \mathrm{p}<0.05\right)$ in the early culture phase, with a significant prevalence of gram-positive rods $\left(\mathrm{F}_{1,26}=25.99 ; \mathrm{p}<0.05\right)$ in all rice growing regions under investigation. The group of spore-forming bacteria was significantly more abundant $\left(\mathrm{F}_{1.30}=14.06 ; \mathrm{p}<0.05\right)$ when compared with the nonspore-forming ones in all investigated regions. Data showed that the irrigated rice crop affects the density and morphotype colonies in the bacteria found in the water used to flood rice-growing plots.
\end{abstract}

Key words: bacterial, rice crop, water, subtropical area.

\section{RESUMO}

\section{Distribuição e densidade de bactérias em áreas subtropicais de cultivo de arroz irrigado no Brasil}

Microrganismos são componentes importantes na estrutura e no funcionamento dos ecossistemas aquáticos, assim, este trabalho objetivou identificar os grupos constituintes das comunidades bacterianas presentes na água de irrigação da cultura do arroz, onde amostras de água foram coletadas em cinco regiões orizícolas do Brasil. A identificação dos principais grupos de bactérias encontrados nas áreas inundadas foi efetuada por meio da morfologia das colônias, sendo avaliados forma, elevação, bordo e estrutura, assim como estruturas internas e externas das células, caracterizando-as como cocos ou bastonetes, gram-positivas ou gram-negativas e esporulantes ou não-esporulantes. Os resultados obtidos quanto à densidade e à distribuição de bactérias em amostras de água de áreas orizícolas do RS revelam maior abundância de morfotipos de colônias bacterianas nos canais de irrigação $\left(\mathrm{F}_{1,12}=8,74, \mathrm{p}<0,05\right)$ quando comparados às parcelas de cultivo das cinco regiões produtoras e na fase final $\left(F_{1,12}=8,86, p<0,05\right)$ da cultura. Nas cinco regiões produtoras de arroz foi predominante a ocorrência de bastonetes, gram- 
positivos e esporulantes. Os bastonetes apresentaram maior número $\left(\mathrm{F}_{1,26}=15,12, \mathrm{p}<0,05\right)$ na fase inicial do cultivo, sendo os gram-positivos predominantes significativamente $\left(\mathrm{F}_{1,26}=25,99, \mathrm{p}<0,05\right)$ em todas as regiões orizícolas estudadas. O grupo de bactérias esporulantes foi significativamente mais abundante $\left(\mathrm{F}_{1,30}=14,06, \mathrm{p}<0,05\right)$ do que as não-esporulantes nas cinco regiões. Os dados obtidos revelam que a cultura de arroz irrigado tem influência na densidade e nos morfotipos de colônias das bactérias presentes na água utilizada na inundação das parcelas.

Palavras-chave: bactéria, colheita de arroz, água, área subtropical.

\section{INTRODUCTION}

Microorganisms can be found in many habitats in soil, air, and water. Even in those places in which the majority of studies have been conducted, e.g., water, very little is known about existing populations and communities. But microorganisms are key elements in water ecosystem structure and function (Gasol \& Duarte, 2000), interacting in their natural habitats with other microorganisms, host organisms, and their physicochemical environment (Zinder \& Salyers, 2001).

According to Rheinheimer (1987), microbiota composition varies as a function of water class, and depends mainly on salt and organic compound concentration, turbidity, temperature, and contamination sources. Thus, bacteria found in the seawater can be different from those of freshwater in rivers and lakes. Many studies have been carried out to identify the microbiota found in freshwater that can indicate water quality, mainly at the surface where anthropogenic events, especially those connected with agriculture, have significant influence.

Profit losses caused in rice crops by pests, such as insects, phytopathogens, and harmful plants have been decreased by the use of phytosanitary treatments. On the other hand, this type of crop management creates environmental sustainability problems, mainly regarding agrochemicals and culture in irrigation. The need to decrease their environmental impacts and to expand knowledge regarding biodiversity in rice fields are currently creating challenges for researchers.

Rice is an annual plant, classified as C-3, adapted to aquatic environments, and cultivated in both low- and highlands of Brazilian ecosystems. In the lowlands, growth-controlled irrigation prevails in about one million hectares in southern Brazil (Rio Grande do Sul and Santa Catarina States), a subtropical region where crop cultures have been managed at both high technological and profit levels (Irga, 2001). However, this requires manure, as well as herbicide and insecticide usage. In addition, the highland ecosystems in the Midwestern region of the country have shown good productivity in nonirrigated rice culture.

Irrigated rice crops in Rio Grande do Sul (RS), which are of major economic importance, are currently being studied as to their environmental impact, since part of the water from rivers, lakes, and dams is used in crop flooding. Regarding flooded soils, Liesack et al. (2000) refer to data about anaerobic organisms, highlighting the structure and function of the microbial groups and their interactions with rice plants.

In tropical climates, irrigation water temperatures reach $36^{\circ} \mathrm{C}$; higher temperatures jeopardize total seedling germination (Irga, 2001). Therefore, this study concentrated on aerobic and facultative bacteria with an optimal development temperature between $25^{\circ}$ and $40^{\circ} \mathrm{C}$, among which planktonic heterotrophic bacteria involved in the carbon cycle stand out. Specifically, this research deals with isolation and multiplication of the bacteria in the samples, estimation and identification of the main bacterial groups found in the various regions of Rio Grande do Sul State, and analysis of the rice culture influence on the bacterial population.

\section{MATERIAL AND METHODS}

\section{Experimental areas and cultural features}

Table 1 shows data on the rice cultivation system in Rio Grande do Sul (RS), taken under conditions of soil flooding. The resulting water lamina, which compensates for losses through evaporation, percolation, and other factors, depends on circumstances such as weather conditions, crop management, soil characteristics, water sources, and cultivar (Irga, 2001). 
TABLE 1

Data on the cultivation features of rice-growing areas of Rio Grande do Sul State in which water samples were collected.

\begin{tabular}{|c|c|c|c|c|c|}
\hline \multirow{2}{*}{ Area data } & \multicolumn{5}{|c|}{ Rice-growing regions } \\
\hline & WB & CD & SC & $\mathrm{NC}$ & $\mathbf{P}$ \\
\hline Cultivar & Embrapa-7 & IRGA-417 & IRGA-417 & Epagri 108 & El Passo-144 \\
\hline Cycle (days) & 140 & 115 & 115 & $>150$ & 122 \\
\hline Seeding & $10 / 15 / 01$ & $11 / 29 / 01$ & $11 / 1 / 01$ & $10 / 10 / 01$ & $11 / 28 / 01$ \\
\hline Flooding & $11 / 27 / 01$ & $1 / 6 / 02$ & $12 / 12 / 01$ & $10 / 10 / 01$ & $12 / 10 / 01$ \\
\hline Draining & $3 / 18 / 02$ & $3 / 20 / 02$ & $4 / 6 / 02$ & $3 / 30 / 02$ & $4 / 1 / 02$ \\
\hline $\begin{array}{l}\text { Manuring } \\
\text { Formula } \\
\text { Dates }\end{array}$ & $\begin{array}{c}5-20-20 \\
10 / 15 / 01\end{array}$ & $\begin{array}{c}5-20-20 \\
11 / 29 / 01\end{array}$ & $\begin{array}{l}2-20-20 \\
11 / 1 / 01\end{array}$ & $\begin{array}{c}0-43-0 \\
10 / 10 / 01\end{array}$ & $\begin{array}{l}5-25-25 \\
11 / 28 / 01\end{array}$ \\
\hline \multicolumn{6}{|c|}{ Phytosanitary treatments } \\
\hline Herbicides & $\begin{array}{l}\text { Propanil+ } \\
\text { Tiobencarb } \\
\text { Clomazone }\end{array}$ & $\begin{array}{c}\text { Pyrazosulfuron } \\
\text { Glyphosate } \\
\text { Clomazone }\end{array}$ & $\begin{array}{c}\text { Quinclorac } \\
\text { Pyrazosulfuron }\end{array}$ & $\begin{array}{c}\text { Quinclorac } \\
\text { Ethoxysulfuron }\end{array}$ & $\begin{array}{l}\text { Clefoxydin } \\
\text { Glyphosate }\end{array}$ \\
\hline $\begin{array}{l}\text { Fungicides } \\
\text { Inseticides }\end{array}$ & $\varnothing$ & $\varnothing$ & $\begin{array}{c}\varnothing \\
\text { Lambdacialotrina }\end{array}$ & $\begin{array}{c}\text { Fentin } \\
\text { hidróxido } \\
\text { Carbendazin } \\
\varnothing\end{array}$ & $\varnothing$ \\
\hline Harvest & $3 / 18 / 02$ & $4 / 5 / 02$ & $4 / 10 / 02$ & $4 / 15 / 02$ & $4 / 8 / 02$ \\
\hline \multicolumn{6}{|c|}{ Meteorological means } \\
\hline Temperature $\left({ }^{\circ} \mathrm{c}\right)$ & 24.10 & $\diamond$ & 20.30 & 22 & 22.60 \\
\hline $\begin{array}{l}\text { Solar radiation } \\
\quad\left(\mathrm{cal} / \mathrm{cm}^{2}\right)\end{array}$ & $\diamond$ & $\diamond$ & 398 & $\diamond$ & 284 \\
\hline $\begin{array}{c}\text { Relative } \\
\text { Humidity }(\%)\end{array}$ & 72.16 & $\diamond$ & 65.50 & $\diamond$ & 81.16 \\
\hline
\end{tabular}

WB = Western Border; CD = Central Depression; SC = Southern Coast; NC = Northern Coast; TP = Plains; $\varnothing=$ without product usage; $\diamond=$ without data.

As shown in Figure 1, there are five rice production areas $\left(28^{\circ} 15^{\prime} \mathrm{S} ; 5^{\circ} 24^{\prime} \mathrm{W}\right)$ in Rio Grande do Sul: the Western Border, Central Depression, Southern Coast, Northern Coast, and the Plains, in which the sampled sites were located, respectively, in the cities of Uruguaiana (1), Restinga Seca (2), Santa Vitória do Palmar (3), Torres (4), and Dom Pedrito (5).

\section{Water samples}

Forty water samples $(100 \mathrm{ml})$ were collected in duplicates, between November 2001 and April 2002 in the above-listed five rice crop areas in RS. Each sample represents a mixture of 10 sub-samples (10-ml aliquots) collected with sterilized Falcon tubes along one linear meter. These samples were homogenized in $100 \mathrm{ml}$ sterilized flasks and maintained at $4^{\circ} \mathrm{C}$ until arrival at the laboratory. Two collection sites were designed for samplings, one in the irrigation channel (IC) and other in the rice crop plot (RC). Over the cultivation cycle, two samplings were done, the first in Phase $1-\mathrm{P}_{1}$ (within 15 days after plot irrigation, between November 2001 and February 2002), and the second in Phase 2 $\mathrm{P}_{2}$ (near harvest or draining of plots, and finishing at the end of April 2002).

\section{Isolation and multiplication of bacteria}

In the laboratory the samples were aseptically seeded in agar nutrient, totalizing 160 plates (Atlas, 1996), and kept in a B.O.D. incubator at $30^{\circ} \mathrm{C}$ for 24 hours. The resulting colonies were microscopically quantified and analyzed as to their morphology (Koneman et al., 1999). After being grouped by morphotype, which was followed by re-streaking in nutrient broth (Atlas, 1996), the colonies were preserved in inclined agar at $4^{\circ} \mathrm{C}$ and glycerol $(10 \%)$ at $-18^{\circ} \mathrm{C}$. 


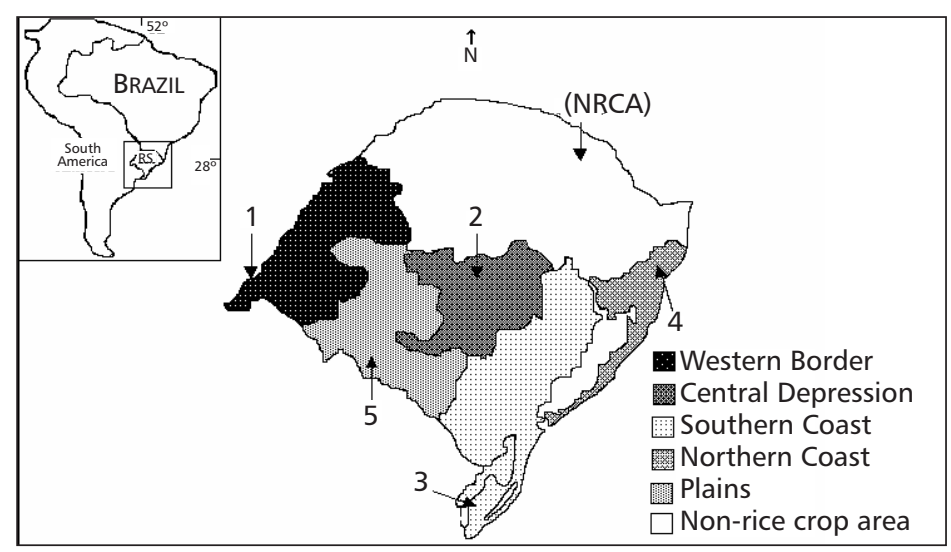

Fig. 1 - Areas of irrigated rice culture in Rio Grande do Sul State with water sampling sites in the towns of (1) Uruguaiana, (2) Restinga Seca, (3) Santa Vitória do Palmar, (4) Torres, and (5) Dom Pedrito.

\section{Bacterial characterization}

Identification of the major bacterial groups found in flooded areas was based on colony morphology and cellular structure and ultrastructure, according to that described in Bergey's Manual of Determinative Bacteriology (Buchanan et al., 1974) as well as an identification key adapted from Yamaoka-Yano \& Valarini (1998), in which specific features of the new bacterial characterization by Boone et al. (2001) were also taken into consideration.

Colony morphology: bacterial colonies were quantified with the help of a colony counter (CP600 , Phoenix), followed by morphotype classification based on shape, elevation, edges, and structure (Koneman et al., 1999).

Cell morphology: colonies were inoculated with nutrient broth and kept in a shaker at $180 \mathrm{rpm}$ and $30^{\circ} \mathrm{C}$ for 18 hours. The samples were then treated by Gram differential staining method (Koneman $e t$ al., 1999) and observed using a 1,000× enhanced optical microscopy. The cells were grouped in rods and cocci and identified by cell-wall composition as either gram-positive or gram-negative ones.

Cell ultrastructure: to detect cells which may or may not form spores, samples were grown according to the previous description, followed by pasteurization (Polanczyk et al., 2000) and cultivation in nutrient broth at $180 \mathrm{rpm}$ and $30^{\circ} \mathrm{C}$ for 18 hours. Assessments were carried out by muddying the culture medium, which indicated the presence of endospore-forming bacterial cells.

Statistical analysis: results were evaluated through factorial analysis of variance (Zar, 1999), with a 0.05 significance level. They were based on colony abundance in areas (WB, CD, SC, NC, P), sampling sites (IC and RC), phases (P1 and P2), and interactions (sampling sites $\times$ phases); bacterial group (i) gram-positive and gram-negative: among groups (gram-positive and gram-negative), sampling sites, phases, as well as interactions among groups $\times$ phases, areas $\times$ groups, and groups $\times$ sampling sites; (ii) sporeforming and non-spore forming among: groups, areas, sampling sites, phases, and interactions (sampling sites $\times$ group; phases $\times$ group). Analyses were performed with Systat 10 software (2000).

\section{RESULTS AND DISCUSSION}

\section{Morphotypes based on features of the bacterial colonies}

Morphotypes of the bacterial colonies found in the water samples for the two cultivation phases and two sampling sites (IC and RC) are found in Table 2.

In the 5 areas 37 morphotypes of colonies were identified: 16 from the water of the irrigation channel, and 7 from the rice crop plot. Fourteen morphotypes were found in both. 
TABLE 2

Amount of bacterial morphotypes, shown in CFUs (colony-forming units) found in selected rice-growing areas of Rio Grande do Sul State.

\begin{tabular}{|c|c|c|c|}
\hline $\begin{array}{c}\text { Colony } \\
\text { morfhotypes }\end{array}$ & $\begin{array}{c}\text { Irrigation } \\
\text { channel }\end{array}$ & Both & $\begin{array}{l}\text { Rice } \\
\text { plot }\end{array}$ \\
\hline 4 & 5 & & \\
\hline 6 & 1 & & \\
\hline 7 & 1 & & \\
\hline 9 & 2 & & \\
\hline 10 & 1 & & \\
\hline 11 & 2 & & \\
\hline 13 & 2 & & \\
\hline 14 & 1 & & \\
\hline 16 & 1 & & \\
\hline 17 & 1 & & \\
\hline 19 & 1 & & \\
\hline 26 & 1 & & \\
\hline 27 & 2 & & \\
\hline 30 & 1 & & \\
\hline 36 & 5 & & \\
\hline 37 & 1 & & \\
\hline 1 & & 130 & \\
\hline 2 & & 60 & \\
\hline 3 & & 16 & \\
\hline 5 & & 22 & \\
\hline 8 & & 26 & \\
\hline 12 & & 5 & \\
\hline 15 & & 31 & \\
\hline 18 & & 8 & \\
\hline 20 & & 3 & \\
\hline 23 & & 2 & \\
\hline 25 & & 19 & \\
\hline 29 & & 4 & \\
\hline 31 & & 7 & \\
\hline 34 & & 4 & \\
\hline 21 & & & 2 \\
\hline 22 & & & 3 \\
\hline 24 & & & 1 \\
\hline 28 & & & 1 \\
\hline 32 & & & 1 \\
\hline 33 & & & 1 \\
\hline 35 & & & 1 \\
\hline
\end{tabular}


The results in Figure 2 refer to the early $\left(\mathrm{P}_{1}\right)$ and final $\left(\mathrm{P}_{2}\right)$ phases of the rice crop, with the data representing the analysis of bacteria abundance in the water samples collected in the five regions of irrigated rice crops. Over the first collecting period $\left(\mathrm{P}_{1}\right)$ (November 2001-February 2002) the mean number of bacterial colonies from the channel (IC) was higher in the Western Border (216) and the Plains (197), followed by the Northern Coast (151) and Central Depression (131), with the least amount in samples from the Southern Coast (81). On the other hand, the mean number of the resulting colonies in the rice crop (RC) plots shows that the highest abundance occurs in the Northern Coast region (84) and the Central Depression region (75), followed by the Southern Coast (47), the Plains (38), and the Western Border (30).

Over the second half of the cultivation cycle $\mathrm{P}_{2}$ (March-April 2002), the same trend of greater in the water reaching the crop through the irrigation channel, if compared to that in the rice crop plot. This can be linked to a possible influence of cultivation management on the bacterial population found in the water samples in addition to factors like manuring and liming, irrigation and draining periods, phytosanitary treatments, and others. But data suggesting such possibilities were not found in the references investigated. However, when these results were compared to studies on soil microorganisms, differences were noticed with respect to analyses conducted by Reichardt et al. (1997) in Philippine rice crop areas. There, intense rice cultivation was observed to reduce or otherwise alter the soil microbial biomass by decreasing nutrient availability. Reichardt et al. (2001) also report the possibility of change during the entire rice-growing cycle in population dynamics of microorganisms that recycle nutrients, as a result of energy input and water regime being considered as determinant factors in endogenous dynamics.

Analysis of the rice-crop phase factors $\left(\mathrm{P}_{1}\right.$ and $P_{2}$ ) relative to the influence of bacterial density shows that this was significantly higher $\left(\mathrm{F}_{1,12}=8.86\right.$; $\left.\mathrm{p}<0.05\right)$ in $\mathrm{P}_{2}$, corresponding to the period before drainage and near the rice harvest, suggesting that the entire cultivation process stimulates bacterial development.

\section{Bacterial groups based on cell characters}

With respect to bacterial characterization, taxonomic groups were identified based on Gram differential staining method and the presence of endospore-forming cells.

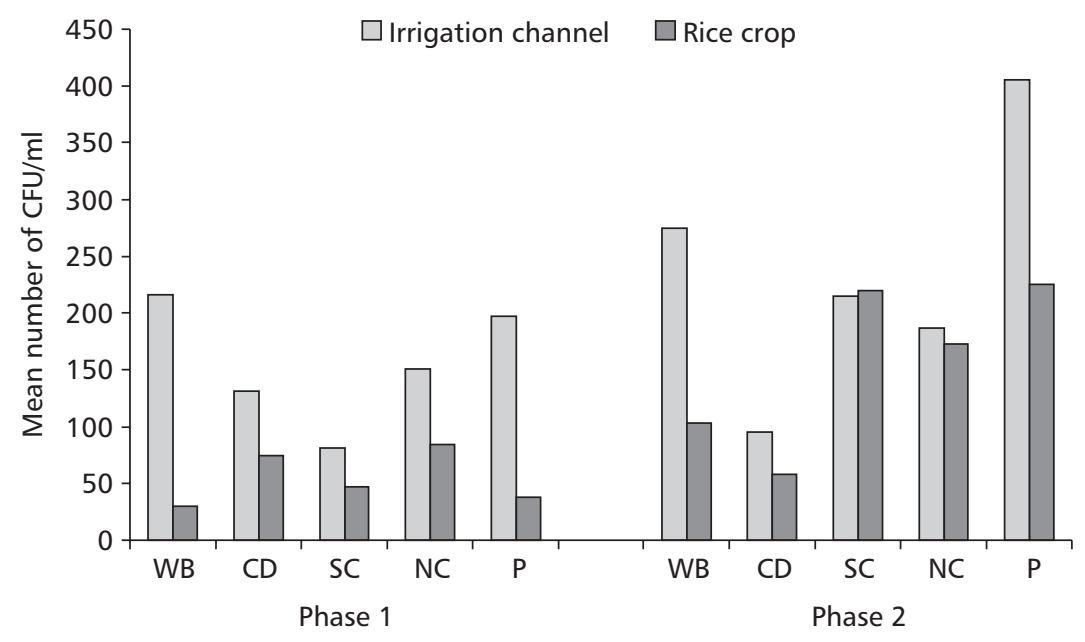

Fig. 2 - CFU mean values of the irrigation channel and rice crop in two phases in five rice-growing areas (Western Border, Central Depression, Southern Coast, Northern Coast, the Plains) of Rio Grande do Sul State. 


\section{Gram-positive and gram-negative bacteria}

The relative occurrence of the groups identified in the five rice crop regions during phases $\mathrm{P}_{1}$ and $\mathrm{P}_{2}$ are represented in Fig. 3. Data of sampling sites from IC and RC are presented in Fig. 4. The analysis of variance (Zar, 1999) showed a major pattern for the abundance of gram-positive bacteria $\left(\mathrm{F}_{1,26}=\right.$ $25.99, \mathrm{p}<0.05)$ when compared to the gramnegative in all five areas. Water in the crop irrigation channel comes from rivers and lakes that may contain non-treated domestic effluents, organic compounds released by industries (Atlas \& Bartha, 1997), and that may also have been impacted by agricultural practices, which contaminate both soil and the aquatic environment (Margni et al., 2002). On the other hand, these compounds may favor the survival of some gram-positive bacteria, the prevalence of which can be correlated with these compounds in the investigated areas. Relative to these findings, data presented by Konopka et al. (1999) on investigations of microbial activity and biomass in soils in Indianapolis presenting organic contaminants and heavy metals also show the occurrence of grampositive bacteria, mainly the Bacillus genus.
Throughout the early phase of cultivation $\left(\mathrm{F}_{1,26}=\right.$ $15.12, \mathrm{p}<0.05)$, the density of gram-positive and gramnegative bacteria was significantly higher than it was in the final phase of the rice crop. Interaction analysis of factors such as region and bacterial group showed a significant difference $\left(\mathrm{F}_{4,26}=2.75, \mathrm{p}<0.05\right)$ when the gram-positive group was prevalent in all five studied regions. But interaction of the other factors, such as cultivation phase (Fig. 3), sampling sites (Fig. 4), and bacterial group (Figs. 3 and 4), shows no significant difference, with the following results being observed: (i) bacteria group $\times$ sampling sites: in the water of the irrigation channel there is a prevalence of gram-positive bacteria; (ii) bacteria group $\times$ cultivation phase: grampositive bacteria were the most abundant throughout the early cultivation phase.

Mattos et al. (2001) isolated gram-negative bacteria in typical hydromorphic flat soil, capable of degrading xenobiotics in an irrigated rice ecosystem. Sampled sites in the Central Depression and Southern Coast show flat, hydromorphic soil, in which the presence of gram-negative groups was evident. But gram-positive cocci were scattered evenly throughout the five regions, although in small numbers.

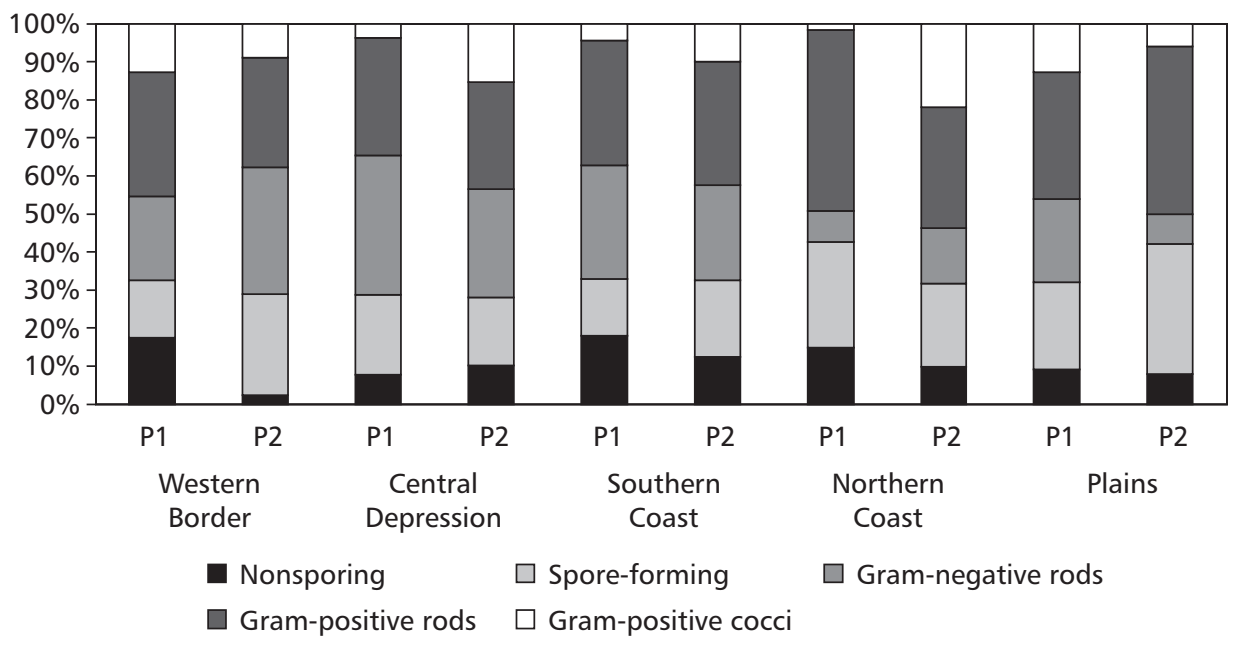

Fig. 3 - Relative occurrence of gram-positive, gram-negative, spore-forming, and non-spore forming bacteria found in phases $\mathrm{P}_{1}$ and $\mathrm{P}_{2}$ of five rice-growing areas in Brazil. 


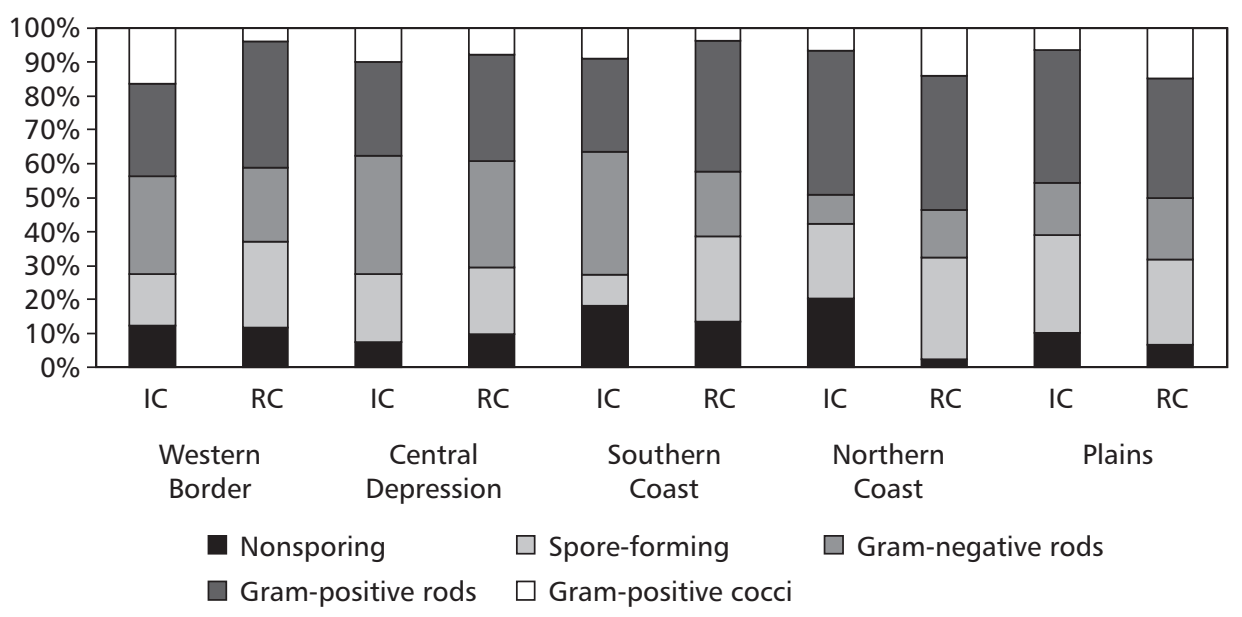

Fig. 4 - Relative occurrence of gram-positive, gram-negative, spore-forming, and non-spore forming bacteria found in sampling sites IC and RC of five rice-growing areas in Brazil.

\section{Spore-forming and non-spore forming bacteria}

When comparing the amount of non-spore forming bacteria and spore-forming bacteria, the latter significantly outnumbered the former $\left(\mathrm{F}_{1,30}=14.06\right.$, p $<0.05$ ) in all studied areas (Fig. 3). The sporeforming bacterial group is characterized by its adaptive capacity to the environment, which makes it harmful to microorganisms, and by being able to remain dormant through endospores. Temperature increases and desiccation may lead to the presence of metabolically inactive bacterial cells. Liesack $e t$ al. (2000) have also reported that microbial populations in flooded rice soils develop the capacity to adapt themselves to alternate environmental conditions of flooding and draining through spore making.

Throughout the cultivation phases, a significantly higher difference $\left(\mathrm{F}_{1,30}=9.28, \mathrm{p}<0.05\right)$ was noticed at the beginning of the process in both groups, with water from the irrigation channel showing a higher density in both groups, although with a non-significant difference $\left(\mathrm{F}_{1,30}=1.37, \mathrm{p}>\right.$ 0.05 ) when compared to the rice crop plot. Water from the irrigation channels shows nutrient-rich compounds from areas subject to anthropic interference, suggesting that the bacterial groups found are saprophytic. These findings lend weight to those presented by Lecler \& Moreau (2002), whose research, carried out with natural mineral water, showed that the latter differs from potable water in its physical-chemical and microbiological characteristics, with the natural mineral water showing the same aerobic and saprophytic bacterial communities, groups of which were also found in the present study.

Over the second half of the cultivation cycle $\left(\mathrm{P}_{2}\right)$ (Fig. 3), a decrease was found in the amount of endospores forming in areas such as the Central Depression and Northern Coast, for which the data resemble results shown by Reichardt et al. (1997) in Philippine rice crops, further substantiating the association between this factor and the intensive irrigated-rice cultivation system. However, in the Western Border, Southern Coast, and the Plains a decrease occurred in non-spore forming bacteria, leading to a similarity of this data to that of irrigated rice crops in other such regions in RS.

Collection results showed that irrigated rice cultivation influences the density of bacterial colony morphotypes found in samples containing the water used in plot flooding. In the five rice-culture regions studied, the occurrence of Gram-positive and sporeforming rods was prevalent, suggesting that they are the most resistant bacterial groups under local crop conditions (Table 1). Therefore, the data presented here can be used as a basis for comparing the bacterial groups, prevalent in this agroecosystem (flooded areas of rice culture), that function as biological indicators of environmental effects on the agricultural cultivation system. 
Acknowledgements - This work was conducted with the cooperation of EEA/IRGA, UNISINOS, and FEPAGRO. It was supported financially by CAPES. We thank the technical team of EEA/IRGA for help in collecting the water samples used in this research. Thanks are also expressed to Gislene Ganade and Regina Garcez.

\section{REFERENCES}

ATLAS, R. M. \& BARTHA, R., 1997, Microbial Ecology: fundamentals and applications. $4^{\text {th }}$ ed. Addison Wesley Longman. The Benjamin/Cumming Publishing Company, Inc., 694p.

ATLAS, R. M., 1996, Handbook of microbiological media. $2^{\text {nd }}$ ed. Lawrence C. Parks, United States of America, 1706p.

BOONE, D. R., CASTENHOLZ, R. W., GARRITY, G. M., STALEY, J. T., BRENNER, D. J., GOODFELLOW, M., KRIEG, N. R., RAINEY, F. A. \& SCHLEIFER, K. H., 2001, The archaea and the deeply branching and phototrophic bacteria. p. 359. In: G. M. Garrity. Bergey's Manual of Systematic Bacteriology. $1^{\text {st }}$ v., 721p. Springer-Verlag, New York.

BUCHANAN, R. E., GIBBONS, N. E., COWAN, S. T., HOLT, J. G., LISTON, J., MURRAY, R. G. E., NIVEN, C. F., RAVIN, A. W. \& STANIER, R. Y., 1974, Bergey's manual of determinative bacteriology. $8^{\text {th }}$ ed. William \& Wilkins, Baltimore, 1268p.

GASOL, M. G. \& DUARTE, C. M., 2000, Comparative analyses in aquatic microbial ecology: how far do they go? FEMS Microbiol. Ecol., 31: 99-106.

IRGA - Instituto Riograndense do Arroz, 2001, Arroz Irrigado: recomendações técnicas de pesquisa para o Sul do Brasil. 3. ed. Cachoeirinha, 128p.

KONEMAN, E. M., ALLEN, S. D., JANDA, W. M., SCHERECKENBERGER, P. C. \& WINN, W. C., 1999, Diagnóstico microbiológico, texto y atlas color. 5a ed. Editorial Medica Panamericana, Buenos Aires, 1432p.

KONOPKA, A.; ZAKHAROVA, T., BISCHOFF, M., OLIVER, L., NAKATSU, C. \& TURCO, R. F., 1999, Microbial biomass and activity in lead-contaminated soil. Appl. Environ. Microbiol., 65: 2256-2259.
LECLERC, H. \& MOREAU, A., 2002, Microbiological safety of natural mineral water. FEMS Microbiol. Rev., 26: 207222.

LIESACK, W., SCHNELL, S. \& REVSBECH, N. P., 2000, Microbiology of flooded rice paddies. FEMS Microbiol. Rev., 24: 625-645.

MARGNI, M., ROSSIER, D., CRETTAZ, P. \& JOLLIET, O., 2002, Life cycle impact of pesticides on human health and ecosystems. Agric. Ecosyst. Environ., 93: 379-392.

MATTOS, M. L. T., MARTinS, J. F. S. \& SANTOS, F. O., 2001, Bactérias degradadoras em solo tratado com carbofuram no ecossistema de arroz irrigado. In: Anais do II Congresso Brasileiro de Arroz Irrigado. IRGA, Porto Alegre, pp. 781-783.

POLANCZYK, R. A., SILVA, R. F. P. \& FIUZA, L. M., 2000, Effectiveness of Bacillus thuringiensis strains against Spodoptera frugiperda (Lepidoptera, Noctuidae). Braz. J. Microbiol., 31: 165-167.

REICHARDT, W., BRIONES, A., JESUS, R. \& PADRE, B., 2001, Microbial population shifts in experimental rice systems. Appl. Soil Ecol., 17: 151-163.

REICHARDT, W., MASCARIÑA, G., PADRE, B. \& DOLL, J., 1997, Microbial communities of continuously cropped, irrigated rice fields. Appl. Environ. Microbiol., 63: 233238

RHEINHEIMER, G., 1987, Microbiología de las aguas. Acribia, S.A., Zaragoza, 299p.

YAMAOKA-YANO, D. M. \& VALARINI, P. J., 1998, Métodos de identificação de bactérias, pp. 369-419. In: I. S. Melo \& J. L. Azevedo (eds.), Ecologia Microbiana. EMBRAPA CNPMA, Jaguariúna, 488p.

ZAR, J. H., 1999, Biostatistical analysis. $4^{\text {th }}$ ed. Prentice-Hall International, New Jersey, 931p.

ZINDER, S. H. \& SALYERS, A. A., 2001, Microbial ecology New directions, new importance. p. 101. In: G. M. Garrity. Bergey's manual of systematic bacteriology. $1^{\text {st }}$ vol., SpringerVerlag, New York, 721p. 